\title{
Impacts Of Exchange Rate Fluctuations And Government Debt On Economic Performance For A Latin American Country
}

Yu Hsing (E-mail: yhsing@selu.edu), Southeastern Louisiana University Aristides R. Baraya (E-mail: abaraya@selu.edu), Southeastern Louisiana University Michael C. Budden (E-mail: mbudden@selu.edu), Southeastern Louisiana University Dawn Wallace (E-mail: dwallace@selu.edu), Southeastern Louisiana University

\begin{abstract}
Applying the autoregressive conditional heteroskedascity (ARCH) model as developed by Professor Robert F. Engle (1982, 2001) and based on a 1970-2002 sample, real GDP was found positively affected by the peso depreciation, the U.S. economy, real M2 money, government spending and the expected inflation rate, and negatively influenced by government debt. The gradual recovery of the U.S. economy is expected to help the Colombian economy. An increase in government spending helps raise real output, but increasing government debt to finance rising budget deficits would reduce national output.
\end{abstract}

\section{Introduction}

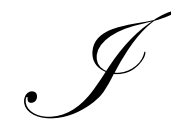

$\mathrm{n}$ recent years, Colombia has experienced currency depreciation, high inflation, high government debt, negative economic growth, high unemployment, and other economic problems. ${ }^{1}$ Colombia's pesos per U.S. dollar depreciated from 18.44 in 1970 to $1,140.96$ in 1997 and continued to depreciate to 2,504.24 in 2002. The dramatic peso depreciation in recent years increased import prices, caused domestic prices to rise, and significantly reduced household purchasing power. A substantial increase in the money supply also accelerated the inflation rate. Currency in circulation, checking account balances, cash values of certificates of deposit and savings accounts, often referred to as M2, rose sharply from 6,034.22 billion pesos in 1990 to some 66,672.2 billion pesos in 2002. That increase in M2 represents an increase of $1,004.9 \%$ in 11 years. As one would expect, Colombia suffered double-digit inflation in the 1990s. Although price increases have moderated somewhat, the inflation rate of $7.97 \%$ in 2001 and $6.35 \%$ in 2002 are still relatively high compared with the rate of inflation in the U.S.

Another negative aspect of recent economic conditions is the relatively high, average lending rate of $16.33 \%$ in 2002. The high cost of borrowing money in Colombia has stagnated business investment. Colombia's government has borrowed heavily from abroad. Government borrowing from foreign sources to finance spending was relatively low in the early1990s, rose rapidly to the equivalent of 1,263.7 billion pesos in 1996, and reached $3,017.1$ billion pesos in 2002. An unfavorable economic environment has led to high unemployment rates and social instability. Colombia's unemployment rate ranged from $10.2 \%$ in 1990 to $20.5 \%$ in 2000 , the most recent data published by the International Monetary Fund. As a result, real GDP at 1994 prices declined sharply from $75,421.3$ billion pesos in 1998 to $72,250.6$ billion pesos in 1999 , but has risen to 76,522.1 billion pesos since.

The purpose of this paper is to estimate the impacts of peso depreciation, government debt, and several other macroeconomic variables on national output or real GDP for Colombia. This paper differs from previous studies in several aspects. First, the theoretical model is built upon the well-known IS-LM analysis, which finds the equilibrium real GDP value based on the equilibrium conditions in both the commodity and the monetary markets. In the commodity market, there are four components, namely, household consumption, business investment, 
government spending, and international trade. The money market consists of the money supply and the money demand. Explanatory variables are specified for each of the components or sectors. Second, it is an open economy model, suggesting that international economic or financial conditions such as the exchange rate and world output are considered. Third, the ARCH model will be employed to estimate parameters for policy implications.

\section{Literature Review}

Thomas Vogel (1999a, 1999b) summarized major economic and political problems in Colombia. These problems included high interest rates, the costly cleanup of a weak banking system with huge bad loan default rates, a failure in monetary policy, an over-valued peso, exhaustion of international reserves to defend the falling peso, low prices for certain commodities, political instability, downgraded international credit, decline in investor confidence, and an anti-drug war that has taken major resources from the government's budget.

Along with economic problems, Colombia has been plagued with drug production and smuggling, kidnapping, violence, assassination, and a 38-year civil war. The U.S. Department of State announced that there are three terrorist groups in Colombia, the largest of which is the FARC (the Revolutionary Armed Forces of Colombia). The FARC occupied a demilitarized zone of about 16,000 squared miles and had approximately 16,500 soldiers to support drug trade and other violent activities. In response, the U.S. government appropriated $\$ 1.3$ billion to create the so-called "Plan Colombia" to fight the drug war (Moffett, 2001; Lifsher, 2002).

Several researchers empirically analyzed Colombia's economy in the areas of inflation, financial liberalization, and the employment market. Ma (1998) found that higher inflation in Colombia caused a greater degree of uncertainty and has a negative impact on national output because inflation causes a distortion of resource allocation, inconvenience, confusion, and a decrease in purchasing power. Barajas, Steiner and Salazar (2000) found that financial liberalization adopted by Colombia in 1990 has led to the opening of foreign banks and has yielded positive impacts such as increased competition, increased efficiency, lower costs, and an improved quality of loans. However, they pointed out that the competition from foreign banks also caused greater risks and a decrease in loan quality for domestic banks serving domestic customers. Ocampo, Sanchez and Tovar (2000) reported that the employment condition in Colombia has deteriorated and that unemployment decreases weigh more heavily or fall more proportionately on relatively low skilled workers.

Several recent articles employed the IS-LM framework to study the impact of changes in the exchange rate and other macroeconomic variables on national output. Based on the sample of twelve developing countries during 1965-1980, Edwards (1986) found that the impact of currency devaluations is negative in the first year, positive in the second year, and neutral in the long run. Further, an increase in unexpected money growth or the government spending/GDP ratio will increase real output.

Iscan (1997) found that in a dynamic model for Mexican peso depreciation there is no effect on real output if three binary variables for devaluations are included, and that the impacts vanish after one year. However, in the static model, peso depreciation causes real output to decrease, and the lagged real interest rate has a negative value. The current real interest rate is insignificant, but the lagged real interest rate is negative and significant. Based on the VAR model, Kamin and Rogers (2000) found that a devaluation of pesos by the Mexican government caused inflation and a decrease in real output, and that it would be risky to manipulate the peso to promote exports without considering possible negative impacts of such a devaluation.

\section{The Model}

It can be inferred that consumption spending is a function of real income and the real interest rate, that investment spending is largely determined by the real interest rate, and that a country's net exports are affected by the real exchange rate and world output. In the money market, money demand is a function of real output and the nominal interest rate. Assume that government tax revenue is proportional to national output and that excessive government debt may negatively impact the economy. The equilibrium condition in the commodity and money markets leads to the following equation: 
$\mathrm{Y}=\mathrm{f}(\mathrm{EX}, \mathrm{WY}, \mathrm{M} 2, \mathrm{GE}, \mathrm{DB}, \mathrm{EI})$

where $\mathrm{Y}=$ real GDP in Colombia;

$\mathrm{EX}=$ the real exchange rate;

$\mathrm{WY}=$ world output;

$\mathrm{M} 2$ = real M2 money;

$\mathrm{GE}=$ government spending;

$\mathrm{DB}=$ government debt as a percent of GDP; and

EI $=$ the expected inflation rate.

In equation (1) above, the real exchange rate affects imports and exports, real M2 money describes monetary policy, and government expenditures and government debt denote fiscal policy. The real exchange rate equals the nominal exchange rate (in this study, in terms of Colombian pesos per U.S. dollar) times the price consumer index (CPI) in the U.S. divided by the CPI in Colombia. Therefore, an increase in EX is a depreciation of the peso's value and a decrease in EX is an appreciation of the peso's value. The impact of changes in the real exchange rate on real GDP is unclear. On the one hand, peso depreciation makes Colombian goods more attractive and stimulates it exports. On the other hand, peso depreciation is likely to increase import prices while raising domestic prices. Higher prices are expected to reduce real income and real wealth and result in lowered household consumption.

When world output rises, other countries are likely to buy more from Colombia as its goods are now relatively cheaper in the world market. The resulting increase in Colombian exports is expected to shift the aggregate demand to the right and raise real GDP. An increase in real M2 money will shift the LM curve to the right, lowering interest rates, and result in a higher real GDP.

An increase in government expenditures will shift the IS curve to the right and cause both the interest rate and real GDP to rise. During the process, there is a multiplier effect because the final increase in real GDP is expected to be greater than the original amount of increase in government spending. The Colombian government needs to borrow money to support continued deficit spending. The impact of government debt on real GDP is expected to be negative because it takes resources away from the private sector and because heavy government borrowing is expected to push up the interest rate and negatively impact business investment and household consumption.

An increase in the expected inflation rate may have two different effects. It is expected to shift the aggregate demand curve to the right due to an increase in current consumption aimed at beating inflation and/or an increase in investment spending attributable to a lower real interest rate. However, it may shift the aggregate supply curve to the left due to the expected higher cost of doing business. The net impact is ambiguous.

\section{Results}

The data used in this study came from International Financial Statistics published by the International Monetary Fund. Sample data ranges from 1970 to 2002. Data before 1970 is not available due to the loss of observations in estimating and calculating the expected inflation rate. In the current study, 1995 was indexed at 100 $(1995=100)$ for real GDP in Colombia. Real GDP in the U.S. is employed to serve as a proxy for world output (WY) as the Colombian economy is highly affected by economic activity in the U.S. WY, M2, and GE are measured in trillions. The average inflation rate for the previous three years is a proxy for the expected inflation rate.

In the $\mathrm{ARCH}$ estimation, error variance is assumed to be a function of past squared error. The estimated variance equation is presented below. As shown, the coefficient of the lagged squared residual is positive and significant at the $1 \%$ level, suggesting that the assumption of the autoregressive conditional heteroskedasticity is appropriate. 
Table 1: Estimated Variance Equation

\begin{tabular}{|l|cccc|}
\hline & Coefficient & S.E. & z-Statistic & Significance \\
\hline $\mathrm{C}$ & 0.2656 & 0.0843 & 3.1488 & 0.0016 \\
$\mathrm{ARCH}(1)$ & 1.2987 & 0.3805 & 3.4130 & 0.0006 \\
\hline
\end{tabular}

The estimated regression based on the autoregressive conditional heteroskedasticity (ARCH) model is reported in Table 2. The value of adjusted $\mathrm{R}^{2}$ is estimated to be 0.9945 , suggesting that $99.45 \%$ of the variation in real GDP can be explained by the six right-hand-side variables. The critical values of $d_{L}$ and $d_{U}$ for the Durbin-Watson $d$ test are 1.061 and 1.900, respectively. Because the value of test statistic falls into the above range, the test for the absence of serial correlation is inconclusive, suggesting that autocorrelation would not be a concern. All other coefficients are significant at the $1 \%$ level. The signs of the coefficients are as expected or are consistent with economic theory.

Several comments can be made. The sign of the coefficient for EX is positive and significant at the $1 \%$ level, indicating that peso depreciation would help raise real output for Colombia. In other words, positive impacts of peso depreciation such as increased exports and reduced reliance on imports would outweigh negative effects of higher domestic prices, lower real income, and lower real wealth. The impact of the U.S. economy is significant. For example, if U.S. real GDP increases by $\$ 1$ trillion, the real GDP index in Colombia will rise by 6.19 . The positive and significant coefficient for real M2 suggests that if real M2 rises by $\$ 1$ trillion, the real GDP index will rise by 1.1030 . The impact of government spending (GE) was found to be significant. If real government spending rises by $\$ 1$ trillion, the index of real GDP will rise by 0.5344 .

It is clear that more government debt negatively impacts real GDP as evidenced by the negative and significant coefficient. Specifically, if the debt/GDP ratio rises by 1 percentage point, the index of real GDP will decline by 0.2899 . The positive and significant coefficient for the expected inflation rate (EI) implies that the positive impact of an increase in EI is greater than the negative impact.

Table 2. Estimated Regression For Colombia's Real GDP Based On The ARCH Model: 1970-2002

\begin{tabular}{|l|ccc|}
\hline Variable & Coefficient & z-statistic & Significance \\
\hline EX & 0.0048 & 5.3010 & $1 \%$ \\
WY & 6.1905 & 11.7975 & $1 \%$ \\
M2 & 1.1031 & 12.7329 & $1 \%$ \\
GE & 0.5344 & 3.3249 & $1 \%$ \\
DB & -0.2899 & -3.3250 & $1 \%$ \\
EI & 0.3506 & 9.6639 & $1 \%$ \\
IN & 0.3309 & 0.2917 & $77 \%$ \\
Adj. R & 0.9945 & & \\
D-W d & 1.2679 & & \\
\hline
\end{tabular}

\section{Discussion And Conclusions}

The determinants of Colombia's real GDP have been examined. The IS-LM model is applied and the ARCH model is employed in empirical work. The relatively high explanatory power suggests that the model fits the Colombian economy quite well. The results can be summarized as follows. Peso depreciation, increased U.S. output, increased real M2, increased government spending, lower government debt, and higher expected inflation are expected to contribute to higher real GDP in Colombia.

There are several policy implications. Although peso depreciation would help raise real output, the dramatic peso depreciation in recent years provides an important lesson in that managers of foreign firms need to monitor exchange rate movements so that their profits will not dwindle. The Colombian government should reduce budget 
deficits and debt so that there is less pressure on financial markets. The decreased pressure on financial markets would lessen interest rates throughout the economy. One positive note is that the Colombian economy is affected by the world economy. If the U.S. economy improves in the near future as predicted by some analysts, the Colombian economy will benefit as well. The positive impact of higher expected inflation may be subject to some limitations as a very high inflation rate would be very harmful to the economy.

\section{Suggestion For Future Research}

The results of this study indicate that there are areas for future research. The consumption function may include stock and non-stock wealth so that household spending can be related to stock market performance. To test the hypothesis that the central bank may stimulate or slow the economy by targeting the interest rate, the ARCH regression model may consider the interest rate to determine whether it explains the dependent variable, as does the supply of real M2. Further, the sample size may be extended providing more degrees of freedom in the model. Finally, quarterly data may be used to capture the dynamic relationship among the macroeconomic variables.

\section{Endnotes}

1. According to the World Bank and the International Monetary Fund, in 2002 Colombia had a population of 43.7 million, a GDP of US $\$ 82.2$ billion, a per capita GNI of US\$1,830, and a total present value of debt of US $\$ 37.6$ billion. Government spending constituted about $20.6 \%$ of GDP. The current budget deficit was $5.6 \%$ of GDP. The inflation rate was 6.3\% during 2001-2002. Services, manufacturing, and agriculture in order were the three largest industries. Major exports in order were manufacturing, petroleum, and coffee products. Major imports were capital goods and foods. The adult literacy rate was $92.1 \%$. The poverty rate was $14.4 \%$.

\section{References}

1. Barajas, Adolfo, Roberto Steiner, and Natalia Salazar (2000): "The Impact of Liberalization and Foreign Investment in Colombia's Financial Sector”, Journal of Development Economics, 63(1), 157-196.

2. Edwards, Sebastian (1986): “Are Devaluations Contractionary?”, Review of Economics and Statistics, 68, 501-508.

3. Engle, Robert F. (2001): GARCH 101: The Use of ARCH/GARCH Models in Applied Econometrics, 15, $157-168$.

4. Engle, Robert F. (1982): “Autoregressive Conditional Heteroscedasticity with Estimates of the Variance of United Kingdom Inflations”, Econometrica, 50, 987-1008.

5. Iscan, Talan (1997): "Devaluations and Aggregate Output Fluctuations: A Random Coefficient Regression Model for Mexico", Applied Economics, 29, 1575-1584.

6. Kamin, Steve B. and John H. Rogers (2000): "Output and the Real Exchange Rate in Developing Countries: An Application to Mexico", Journal of Development Economics, 61, 85-109.

7. Ma, Henry (1998): "Inflation, Uncertainty, and Growth in Colombia", IMF Working Paper: WP/98/161.

8. Lifsher, Marc (2002): "Will U.S. Take A Bigger Role in Colombia?", The Wall Street Journal, February 22, A13.

9. Moffett, Matt (2001): “Colombia's Woes Are Highlighted by Attacks on U.S.”, The Wall Street Journal, September 24, A16.

10. Ocampo, Jose Antonio, Fabio Sanchez, and Camilo Ernesto Tovar (2000): "The Labour Market and Income Distribution in Colombia in the 1990s", CEPAL Review, 0(72), 53-77.

11. Salisbury, Steve (2002): "The Americas: Now We Have a Latin Peace Process in Colombia", The Wall Street Journal, January 18, A11.

12. The Economist (2001): Survey: The Decline of the Coffee Republic, 359(8218), April 21, S8.

13. Vogel, Thomas T., Jr. (1999a): "Colombia's Banks Sink Deeper under Bad Loans Despite Government's Aggressive Cleanup Effort”, The Wall Street Journal, July 29, P. 1.

14. Vogel, Thomas T., Jr. (1999b): “Colombia's Economy Contracts by 7.6\% - Myriad Crises Drive Nation Deeper Into Recession; President's Plea for Aid”, The Wall Street Journal, September 23, P. 1. 
Notes 